\title{
PEST PROBLEMS OF COCONUT HYBRID PRODUCTION IN INDONESIA WITH SPECIAL REFERENCE TO SCDP ${ }^{1}$
}

\author{
by \\ Dante R.A. Benigno, PhD. (Crop Protection Specialist) \\ and \\ Ir. Soetardjo Soewarno (Project Manager)
}

\section{INTRODUCTION}

SCDP is a World Bank and Government of Indonesia fundect project managed by the Directorate General of Estates of the Ministry of Agriculture. This project is responsbile for the planting of coconut hybrids as well as local talls, but mostly hybrids. Since 1981 to date, some 22,000 ha have already been planted to hybrids in 70 coconut working centers (CWC) widely scattered in 6 provinces such as Aceh, Lampung, South Sulawesi, Central Sulawesi, North Sulawesi, and Maluku (Fig.1).

At present, three hybrids (MYD x WAT, MRD x WAT, and NYD x WAT) ${ }^{2}$, are used in the planting program. Because these three hybrids are new under Indonesian conditions, it was deemed necessary to monitor the kinds of pest attacking these hybrids. Therefore, in 1982 a surveillance and early warning system was set-up with the following objectives: to detennine whether these hybrids are equally susceptible to the major pests of the local coconut varieties, and to determine which pests are of econornic importance in each CWC and Province.

It is not the intention of this paper to present the results of research for there are none, nor to describe the pests of coconuts in Indonesia for most of thern are already well described (Van der Laan, 1981), but to provide informations on the pest problems smallholder coconut farmers encounter in growing these hybrids from the nursery to the field. It is, hoped, however, that by presenting these pests problems, coconut researchers, particularly in the fields of crop protection and breeding, are provided feed backs and be guided accordingly in setting up their research priorities on the control of these coconut pests.

\section{MAJOR PESTS IN THE NURSERY}

Coconut pests can be conveniently divided into four groups; the invertebrate pests, vertebrate pests, plant pathogens (diseases), and weeds.

In the nursery, these groups were all observed to be present. However, the plant pathogens seem to be more common than the others. The plant pathogens of importance arc the fungi and MLO. The major diseases caused by these pathogens arc LEAFSPOTS (Caused by Helminthosporlum sp. and Pestalotiopsis (Pestalotia) palmarum), SPEAR ROT (caused Fusarium sp.), and DRY BUD ROT (caused by MLO and transmitted by a planthopper).

The invertebrate pests of importance are insects (Aspidiotus destructor, Plesispa reichei and Valanga nigricornis) and a species of red spider mite (Tetranychus sp.). They are mostly abundant during the dry season.

\footnotetext{
${ }^{1}$ Smallholder Coconut Development Project

${ }^{2}$ MYD $=$ Malayan Yellow Dwarf; MRD $=$ Malayan Red Dwarf; NYD $=$ Nias Yellow Dwarf; WAT $=$ West African Tall.
} 
For the vertebrate pests, rats and wild pigs are very important especially when the nursery is located near a forested area.

\section{MAJOR PESTS IN THE FIELD}

In terms of prevalence, area affected, and damaged caused, the invertebrate and vertebrate pests are, so far, more important than the plant pathogens.

\section{Invertebrate Pests}

During the past three years, the invertebrate pests of importance in coconut hybrid fields were the leaffeeding insects, particularly the beetles and caterpillars.

Beetles. The rhinoceros beetle (Oryctes rhinoceros) is still the number one beetle pest of coconut hybrids, especially to newly transplanted palms. It was particularly important in four provinces: Maluku, North Sulawesi, Central Sulawesi and South Sulawesi. In Lampung and Maluku provinces, Brontispa longissima is now one of the major insect pests of these hybrids. Last year, Promecotheca cumingii started to appear in SCDPfields in Central Sulawesi where there were high incidence in the local talls. Rhynchophorus ferrugineus var. schach has killed a few hybrids in North sulawesi and South Sulawesi. In both cases, however, high incidence of Oryctes had been observed.

Caterpillars. Among the caterpillars of economic importance were the leaffeeders. In the last three years Parasa lepida, Thosea lutea and Hidari Irava were of high incidence in Lampung province; Chalcocelis albiguttata in Maluku; and Darna catenata in North and Central Sulawesi.

Another caterpillar attacking female flowers, Tirathaba rufina, is fast becoming an important pest in all the provinces. It has caused heavy infestations in areas where hybrids are in their first year of flowering.

Long-horned grasshoppers. Although Sexava spp. are very important pests of local tall coconuts in Indonesia, at present they have not caused much damage yet to coconut hybrids in SCDP fields. Lately, however, they have been observed in a few CWCs located in the islands of Halmahera and Seram in the province of Maluku.

Sucking insects. Of the sucking insects feeding on coconut hybrids, the scale insect (Aspidiotus destructor) and whitefly (Aleurodicus destructor) are the most important. The former is widely distributed whereas the latter is becoming an important pest in Central and South Sulawesi provinces.

\section{Vertebrate Pests}

Wild pigs (Sus spp.) and rats (Rattus tiomancis) are the most common vertebrate pests in the field. Wild pigs are particularly important in areas located near or at the edge of the forest. They atttack newly transplanted areas, uprooting the seedlings and then eat the meat still intact in the nut. Rats, on the other hand, attack both the non-bearing and bearing palms. In non-bearing palms they chew the petioles causing them to break and dry up prematurely. In bearing trees, they feed on the green nuts. Rats are particularly abundant in fields with very thick cover crops.

\section{Plant Pathogens}

Fungi are the most important group of plant pathogens in SCDP fields. The fungus Phytophthora palmivora, causing bud rot disease in both immature and mature trees, is the most 
important at the moment. Observations indicate that where there is high incidence of Oryctes and/or Rhynchophorus beetles there is also high incidence of bud rot disease.

Other fungi commonly present are Helminthosporium sp. and Pestalotiopsis palmarmn, both causing leafspot diseases.

\section{OTHER PESTS OF COCONUT HYBRIDS OBSERVED AND/OR REPORTED OUTSIDE SCDP FIELDS.}

\section{Insect Pests}

Beetle. Exopholis hypoleuca (its grub feed on the roots and the adult feeding on the leaves) was observed in a hybrid coconut field in West Java and reported occurring in hybrid demplots in North Sulawesi, Bengkulu, and Bali (Wiryosoehardjo \& Budiman. 1985).

Caterpillars. Artona catoxantha had been reported occurring in North Sumatra (Ginting \& de Chenon, 1985),- Batrachedra arenosella had been reported occurring in hybrid demplots iii North Sulawesi, Bengkulu, and Bali (Wiryosoehardjo \& Budiman, 1985);Ploneta diducta was observed in Central Java.

\section{Vertebrate Pest}

Squirrel. Callosciurus sp. was reported occurring in hybrid demonstration plots in South Sumatra and South Sulawosi (Wiryosoehardjo \& Budiman, 1985).

\section{Diseases}

Stem bleeding. This disease, which is caused by the fungus Ceratostomella (Thielaviopsis) paradoxa, has been reported occurring in several demplots located in West Sumatra, South Surnatral, Bengkulu, Lampung, Bali, West Nusa Tenggara, North Sulawesi, Central Sulawesi, South Sulawesi, Sulawesi Tenggara, and Maluku (Wiryosoehardjo \& Budiman, 1985). A number of hybrids of bearing age have been killed in Maluku.

Immature nut fall. This is caused by the fungusPhytophthora palmivora and reported occurring in hybrid demplots in Lampung (Wiryosoehardjo \& Budiman, 1985) and North Surnatra (Bennet, Sitepu \& Roboth, 1985).

Leafspots. Three species of fungi causing leafspot diseases were reported by Surnardiyono and Triharso (1985). These were Curvularia sp., Alternaria sp., and Nigrospora sp.

\section{SUMMARY}

1. As of April 1985, some 36 invertebrate pests, 3 vertebrate pests, 6 diseases, and 4 nutritional disorders were reported from the $70 \mathrm{CWCs}$ (Table 1). Although there were several weed species growing in farmers' fields, only alang-alang (Imperata cylindrica), was given due attention.

2. The importance of a pest varies with location. Some are important only in a few locations while others are important in several locations. In addition, several insect pests vary in species or varieties in certain locations (Table 1).

3. In the nursery, diseases are more important than insect pests, whereas the reverse is'true in the field. The diseases that have reached epidernic proportions in the nursery were the leafspots -used by Helminthosporium sp. and Pestalotiopsis palmarum. 1 he insect pests that have reached 
epidernic proportions in the field were Parasa lepida, Thosea lutea, Darna catenata, Chalcocelis albiguttata, Brontispa longissima, and Oryctes rhinoceros.

\section{CONCLUSION}

Observations made on the pest populations in the $70 \mathrm{CWSs}$, in the past three years, have shown that all the three hybrids are equally susceptible to all the pests of the local coconut varieties in Indonesia. Likewise, they are quite sensitive to nutritional deficiencies or imbalances in the soil, particularly to nitrogen and boron.

The experience of SCDP in its pest monitoring shows further that crop protection wfll, undoubtedly, play a very important role in the cultivation of coconut hybrids in this country.

\section{SUGGESTED RESEARCH AREAS}

1. Biological control of the major insect pests of coconut must be looked into particularly in mass rearing methods and release of the biological agents.

2. More tests on microbial insecticides (bacteria, fungi, viruses) either applied alone or in combination with standard chernical insecticides thereby reducing built up of insect resistance and effects on the environment, and on parasites and predators.

3. Developing more, efficient techniques of applying pesticides to very tall coconut trees.

4. Incorporating pest resistance to hybrids being developed, particularly to the leaffeeding insects and to certain diseases affecting the whole tree.

\section{REFERENCES}

Bennett, C.P.A., Sitepu, G. \& Roboth, O. 1985. Aspek pernberantasan penyakit gugur buah Kelapa, Cocos nucifera L. yang disebabkan Phytophthora palmivora (Butler) Butler. Mimeographed, $4 \mathrm{p}$.

Ginting, C.U. \& de Chenon, R. D. 1985. Teknik infus akar untuk melindungi kebun benih sepanjang tahun. Seminar Proteksi Tanaman Kelapa. Bogor, 8 - 10 May 198 5. Mimeographed. 26 p.

Surnardiyono, Y.B. \& Triharso. 1985. Pengelolaan penyakit daun pada tanaman kelapa. Serninar Proteksi Tanaman Kelapa, 8 - 10 May 1985. Mimeographed, 9 p.

Van der Laan, P.A. 1981. Pests of Crops in Indonesia. P.T. Ichtiar Baru-Van Hoeve, Jakarta, Indonesia, $701 \mathrm{p}$.

Wiryosoehardjo, S. \& Budiman, A. 1985. Situasi hama dan penyakit tanaman kelapa di Indonesia. Seminar Proteksi Tanaman Kelapa, Bogor, 8 - 10 May 1985. Mimeographed, 39 p. 
Table 1. Distribution of Pests of Coconut Hybrids at SCDP.

\begin{tabular}{|c|c|c|c|c|c|c|}
\hline \multirow{2}{*}{$\begin{array}{c}\text { PEST MONITORED } \\
\text { FROM JANUARY } 1982 \text { TO } \\
\text { APRIL } 1985\end{array}$} & \multicolumn{6}{|c|}{ P R O V I N C E } \\
\hline & Aceh & Lampung & $\begin{array}{c}\text { South } \\
\text { Sulawesi }\end{array}$ & $\begin{array}{c}\text { Central } \\
\text { Sulawesi }\end{array}$ & $\begin{array}{c}\text { North } \\
\text { Sulawesi }\end{array}$ & Maluku \\
\hline INVERTEBRATE PESTS & & & & & & \\
\hline Brontispa longissima & - & $* *$ & - & - & - & - \\
\hline B. longissima var.selebensis & - & - & * & - & * & ** \\
\hline Leucopholis sp. & - & - & - & - & * & - \\
\hline Oryctes rhinoceros & * & * & ** & ** & ** & ** \\
\hline Plesispa reichei & * & * & * & * & * & * \\
\hline Promecotheca cumingii. & - & - & - & ** & - & - \\
\hline Rhynchophorus ferrugineus & - & * & - & - & - & - \\
\hline R. ferrugineus schach & - & - & $*$ & - & $*$ & - \\
\hline Amathusia phidippus & * & * & 0 & * & - & - \\
\hline Artona catoxantha & 0 & 0 & - & - & - & - \\
\hline Cephrenes chryosoma & - & - & $*$ & * & * & * \\
\hline Chalcocelis albiguttata & - & - & - & - & 0 & ** \\
\hline Darna catenata & - & - & * & ** & ** & - \\
\hline D. trima & * & * & - & - & - & - \\
\hline Hidari irava & * & ** & 0 & 0 & 0 & 0 \\
\hline Mahasena corbetti & * & * & * & * & * & * \\
\hline Parasa lepida & - & ** & 0 & - & - & - \\
\hline Ploneta diducta & - & 0 & - & - & - & - \\
\hline Setora nitens & $*$ & $*$ & * & $*$ & 0 & - \\
\hline Thosea asigna & - & - & * & - & * & - \\
\hline Tbosea lutea & * & ** & - & - & - & - \\
\hline Tirathaba ruflvena & * & $* *$ & $* *$ & $*$ & $* *$ & $*$ \\
\hline Trichogyia albistrigella & - & - & - & $*$ & $*$ & - \\
\hline Aleurocanthus sp. & * & 0 & $*$ & - & * & - \\
\hline Aleurodicus destructor & $*$ & 0 & $*$ & $*$ & $*$ & 0 \\
\hline Aspidiotus destruclor & * & * & $*$ & * & $*$ & * \\
\hline Astegopterix spp. & * & * & * & * & * & * \\
\hline Cerataphis lataniae & * & 0 & * & 0 & * & - \\
\hline Hysteroneura setariae & * & * & - & - & * & - \\
\hline Pseudoccocus sp. & * & * & * & * & 0 & * \\
\hline Stephanitis typicus & * & * & - & * & 0 & * \\
\hline Tetranychus sp & - & $*$ & - & - & $*$ & - \\
\hline Sexava coriacea & - & - & - & - & - & $*$ \\
\hline S. nubila & - & - & - & - & - & * \\
\hline Valanga nigricornis & $*$ & $*$ & * & * & * & * \\
\hline Coptotermes curvignathus & - & $*$ & - & - & $*$ & - \\
\hline VERTEBRATE PESTS & & & & & & \\
\hline Bear & 0 & - & - & - & - & - \\
\hline Rat & * & * & * & * & * & ** \\
\hline Wild pig & $* *$ & $* *$ & $* *$ & * & * & * \\
\hline
\end{tabular}




\begin{tabular}{|c|c|c|c|c|c|c|}
\hline & \multicolumn{6}{|c|}{ P R O V I N C E } \\
\hline & Aceh & Lampung & $\begin{array}{c}\text { South } \\
\text { Sulawesi }\end{array}$ & $\begin{array}{c}\text { Central } \\
\text { Sulawesi }\end{array}$ & $\begin{array}{c}\text { North } \\
\text { Sulawesi }\end{array}$ & Maluku \\
\hline $\begin{array}{l}\text { DISEASES } \\
\text { Dry bud rot } \\
\text { Helminthosporium leafspot } \\
\text { Pestalotiopsis leafspot } \\
\text { Marasmius basal rot } \\
\text { Phytophthora bud rot } \\
\text { Spear rot } \\
\text { NUTRIENT DEFICIENCY } \\
\text { Boron } \\
\text { Magnesium } \\
\text { Nitrogen } \\
\text { Potassium }\end{array}$ & $\begin{array}{l}- \\
* \\
* \\
* \\
* \\
*\end{array}$ & $\begin{array}{l}* \\
* \\
* \\
* \\
* \\
*\end{array}$ & $\begin{array}{c}- \\
* \\
* \\
- \\
* * \\
*\end{array}$ & $\begin{array}{l}- \\
* \\
* \\
- \\
* \\
*\end{array}$ & $\begin{array}{c}- \\
* \\
* \\
- \\
* * \\
*\end{array}$ & $\begin{array}{l}- \\
* \\
* \\
- \\
0 \\
*\end{array}$ \\
\hline
\end{tabular}

Legend :

$* *=\quad$ high incidence

$*=$ reported and confirmed

- $=$ no report or not yet observed

$0=$ reported, but not confirmed
Number of CWC per Province:

\begin{tabular}{lr} 
D.I. Aceh & 6 \\
Lampung & 8 \\
South Sulawesi & 12 \\
Central Sulawesi & 12 \\
North Sulawesi & 24 \\
Maluku & 8 \\
\multicolumn{1}{r}{$\quad$ Total } & 70
\end{tabular}




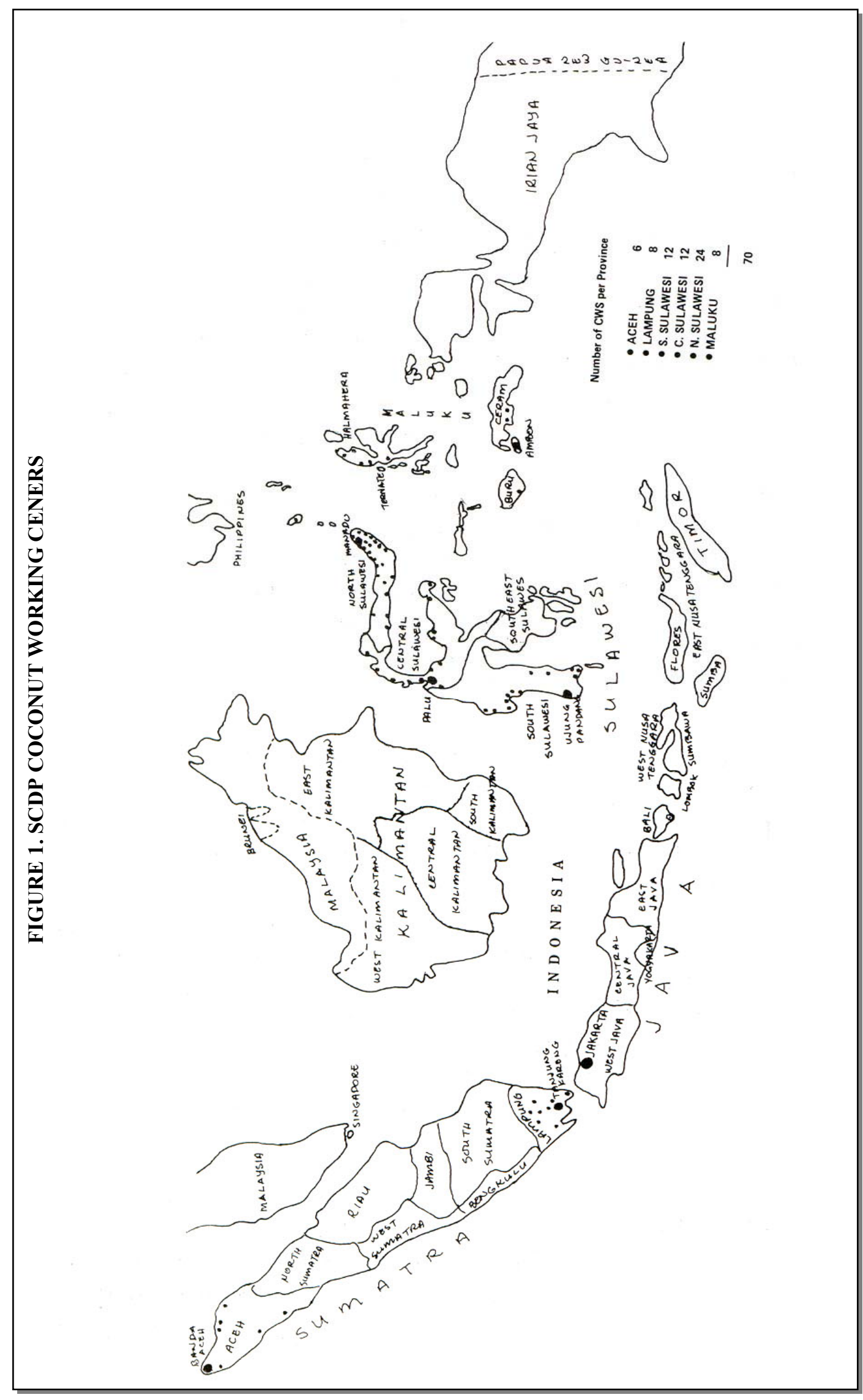

